\title{
Renewable energy systems implementation in road transport: prospects and impediments
}

\author{
Amela Ajanovic ${ }^{*}$ and Reinhard Haas \\ Energy Economics Group, Vienna University of Technology (TU WIEN), Vienna, Austria
}

Received: 30 June 2021 / Received in final form: 8 October 2021 / Accepted: 8 October 2021

\begin{abstract}
The transport sector accounts for about one quarter of the global carbon dioxide emissions. It is dominated by fossil fuels, leading to different negative impacts on humans and the environment. Over the last years, interest in alternative automotive powertrains such as different types of electric vehicles as well as lowcarbon fuels has been increasing. The main objective of this paper is to provide review of the current state of the major renewable energy systems in road transport focusing on the EU. Based on a detailed literature review, the major prospects and impediments for the future use of biofuels, renewable electricity and green hydrogen in road transport are discussed considering policies implemented, as well as emission reduction targets set for the future with a special focus on passenger car transport. The major conclusions are: (i) The prospects of biofuels depend on their future economic and environmental performance as well as on land availability and the food versus tank discussion. (ii) The high investment costs of battery- and fuel cell electric vehicles are still a major barrier for their faster market penetration but they could be reduced in future due to technological learning. In addition, their contribution to the reduction of global greenhouse gas emissions is achievable only in combination with the increasing use of renewable energy sources in electricity generation.
\end{abstract}

\section{Introduction}

For a long time, transport was based on renewable energy sources, mostly horses fed on biomass, and wind, which powered sailing ships, see Figure 1. With the beginning of the industrial revolution and its new technical inventions, renewable energy was widely replaced by commercial fossil fuels. At the same time the demand for mobility, and therefore for energy skyrocketed. Currently, the largest amount of energy used in the transport sector is provided by fossil fuels, about $96 \%[1,2]$.

This rapid development over the last century has unfortunately not been without consequences for the environment and our health. Global greenhouse gas (GHG) emissions are increasing continuously as well as air pollution, especially in urban areas. According to the World Health Organization (WHO) about 7 million people die every year of diseases caused by air pollution [3]. Due to the negative impact of mobility based on fossil fuels, many countries and regions have prioritized the reduction of emissions in the transport sector.

\footnotetext{
* e-mail: ajanovic@eeg.tuwien.ac.at
}

The transport sector accounts for about one quarter of the world's total energy consumption [4]. However, the largest percentage is accounted for by road transport. For example, in 2018, road transport was responsible for $89 \%$ of the total energy consumption in transport in International Energy Agency (IEA) member countries [5], see Figure 2.

Continuously increasing energy consumption in road transport is dominated by fossil fuels, especially gasoline and diesel [6]. Due to pressing environmental problems, there is an urgent need to reduce greenhouse gas emissions and improve local air quality.

Over the last years, interest in alternative automotive powertrains and alternative, low-carbon fuels based on renewable energy sources has been increasing. Currently, the common alternatives to fossil fuels and conventional internal combustion engine (ICE) vehicles are biofuels and different types of electric vehicles, including fuel cell vehicles refuelled with hydrogen.

All currently available alternative fuels and automotive technologies have their advantages and disadvantages. The major advantage of biofuels is that they can be blended with conventional fuels, gasoline and diesel, can be used in conventional cars and do not require new infrastructure. 


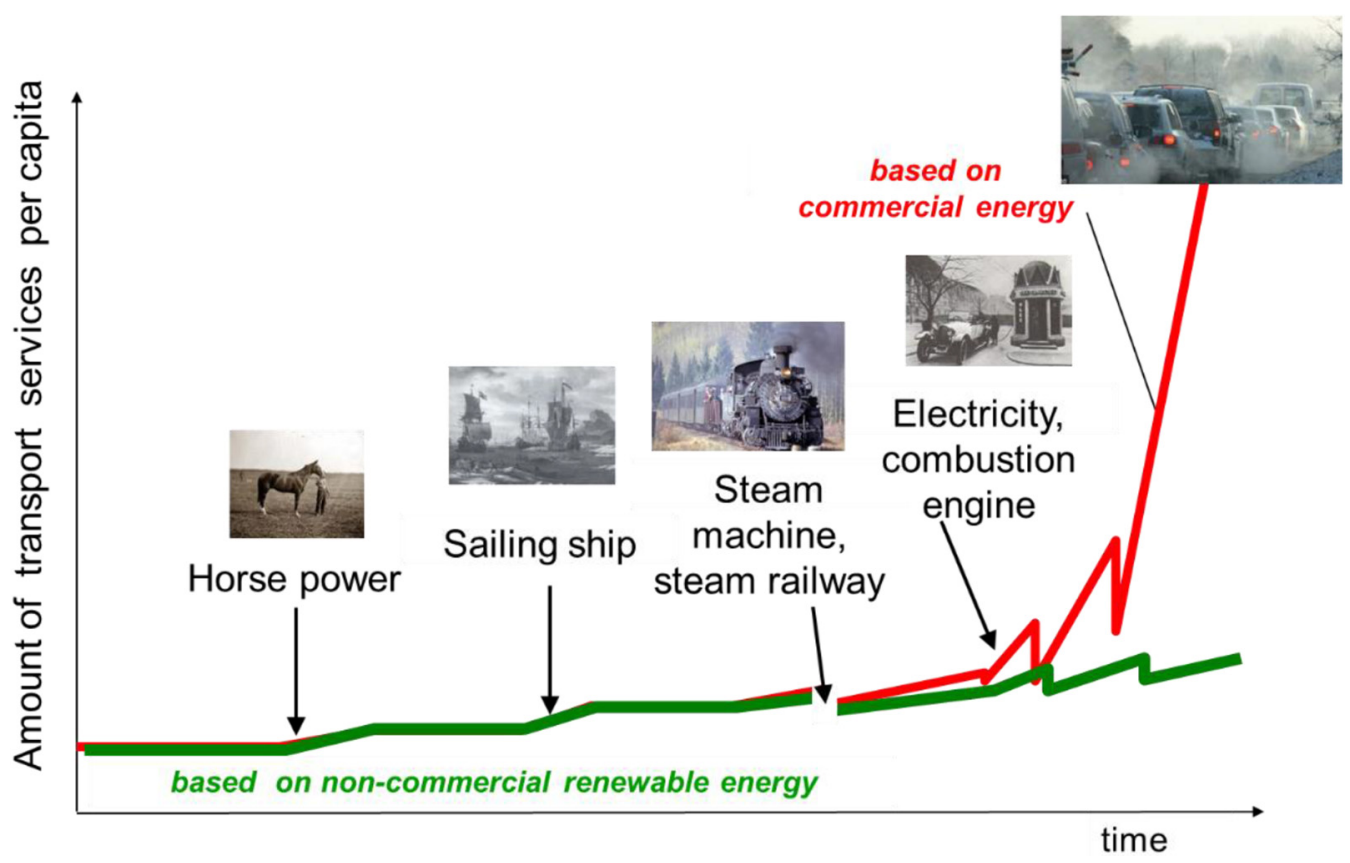

Fig. 1. Development of transport service.

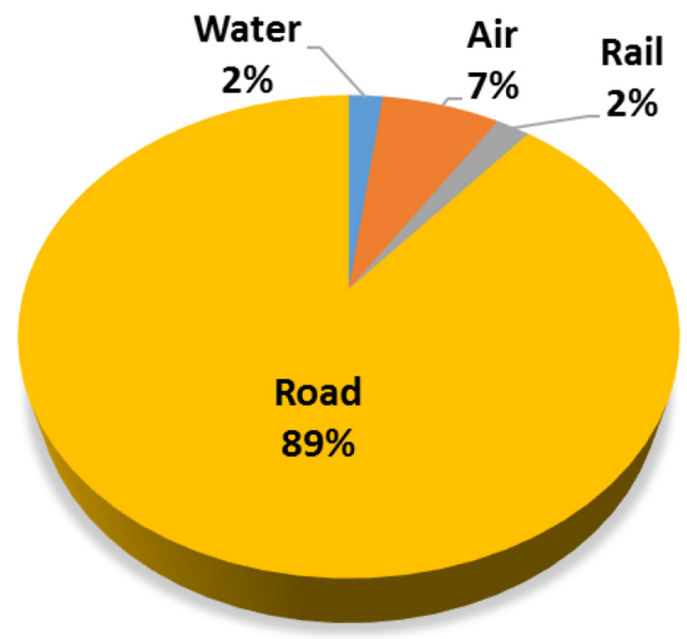

Fig. 2. Energy consumption in transport in IEA countries, 2018 [5].

However, 1st generation biodiesel and bioethanol, which are currently in use, are produced from feedstocks, which are also used in food- and feed-production. This could lead to competition between food and fuel.

Electric vehicles have the potential to reduce local air pollution, as well as GHG emissions. However, the extent to which they will be beneficial for the global environment is very dependent on the primary energy sources used for electricity generation and hydrogen production.

For the faster and broader introduction of electric vehicles it is very important to reach a further cost reduction, to improve battery performance, as well as to accelerate infrastructure development.
The current implementation of a broad portfolio of policies aims at increasing the use of alternative fuels and vehicles.

However, despite of the broad portfolio of the policies implemented, the transport sector is still not on the track to reach emission reduction targets for 2030 and 2050 [7]. Although, energy efficiency of automotive technology is increasing, global energy demand in the transport sector is continuously growing mostly due to increasing number of vehicles in the road transport.

Due to the increasing size of vehicles and additional services, important technical improvements, which have been made to engine and other vehicle components, have been largely offset by heavier, larger and more powerful vehicles. These developments have resulted in almost continuously increasing GHG emissions from the transport sector. Worldwide, the transport sector is responsible for about one-quarter of total GHG emissions with the increasing trend. Largest amount of the emissions from the transport sector is caused by the road transport, since road transport accounts for around three-quarters of global transport energy use [4]. Energy demand in the transport sector is continuously growing and is almost completely covered by fossil fuels. In 2018, share of transport in total final energy consumption was 29\%. However, largest amount of these energy, $96.3 \%$ was met by fossil fuels, $3.4 \%$ by biofuels and just $0.3 \%$ by renewable electricity $[1,2]$. To reach the goals of the Paris Climate Agreements, as well as different regional and national targets, use of renewable energy in the transport sector should be significantly increased.

Although, increasing use of renewable energy sources and reduction of the GHG emissions is one of the priorities of the EU energy and transport policy, GHG emissions from the transport have been almost continuously growing 


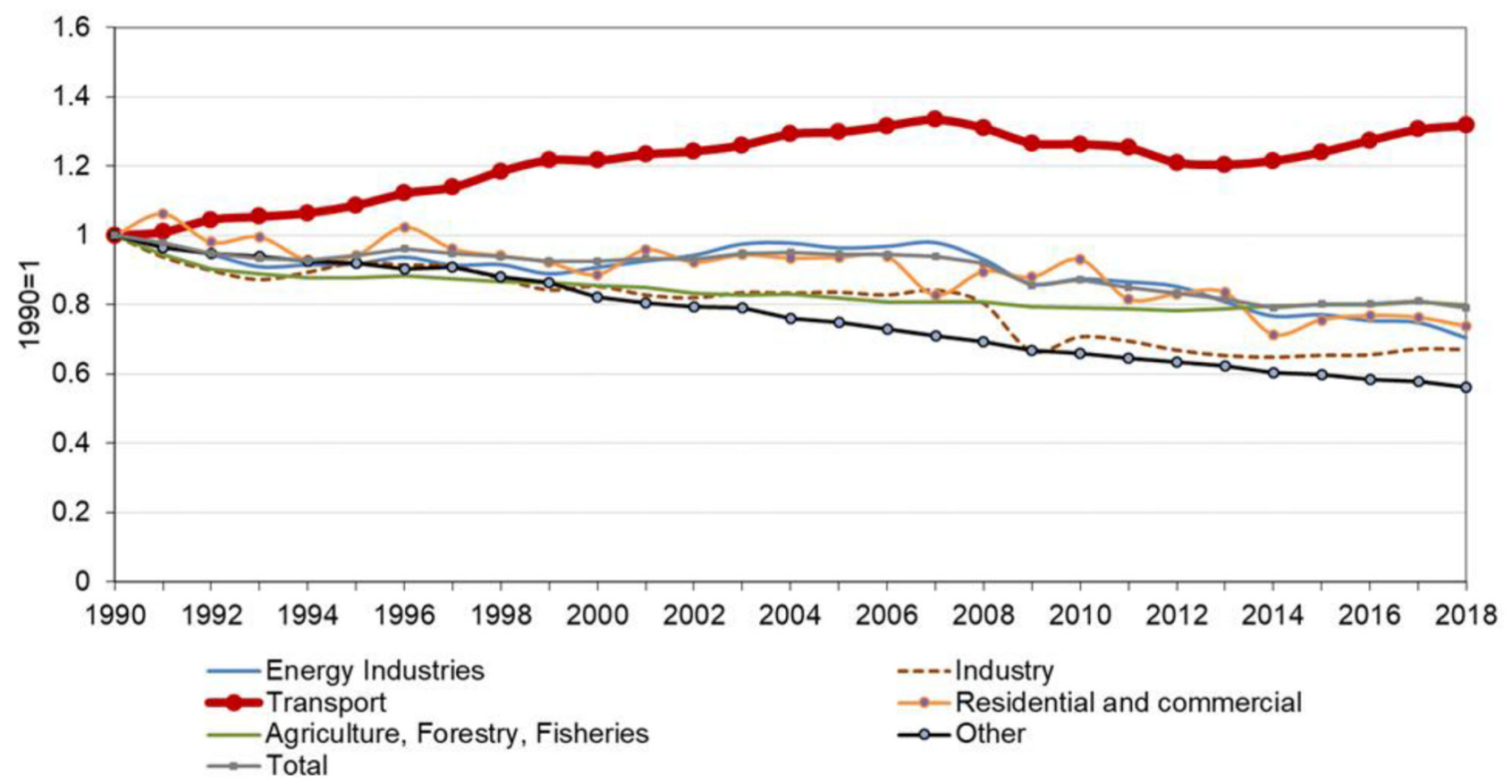

Fig. 3. Development of GHG emission in the EU [8].

over the last decades [8], see Figure 3. The transport sector is the least energy-diversified sector with a very high energy import dependency in Europe.

The mostly used vehicles in the EU are conventional ICE vehicles powered by gasoline, almost $60 \%$ [9], followed by diesel vehicles. In spite of different supporting measured provided for alternative automotive technologies, in 2019, mostly sold cars in the EU were still conventional cars, see Figure 4.

Over the last years, alternative fuels and alternative automotive technologies have been investigated in many scientific papers. In the beginning of the last decade, major focus was put on conventional biofuels, bioethanol and biodiesel. The benefits and challenges of biofuels have been discussed in several scientific papers [10-13]. Political, economic and environmental impacts of biofuels are often discussed in the literature [14-16]. Hammond et al. [17] have analysed environmental footprint of biofuel production. Water and land use for biofuels have been analysed by Ayres [18] and Wise et al. [19] respectively. Impact of biofuels production on food is discussed by Srinivasan [20], Rathmann et al. [21], and Ajanovic [22].

Recently major focus is on electrification of mobility. Different aspects of electric vehicles, as well as hydrogen economy and hydrogen technologies are discussed in scientific papers [23-25]. Some of the papers are focusing on the use of electric vehicles in urban areas [26-28]. Many authors have conducted environmental assessment of emobility [29-31]. However, due to changeable policy framework and technical improvements the discussion on all alternative fuels and alternative automotive technologies started again.

Most literature focusses either solely on biofuels, or battery electric vehicles or hydrogen and fuel cell vehicles. Very few papers analyse all these renewable energy systems together, e.g. $[32,33]$. This review paper provides a

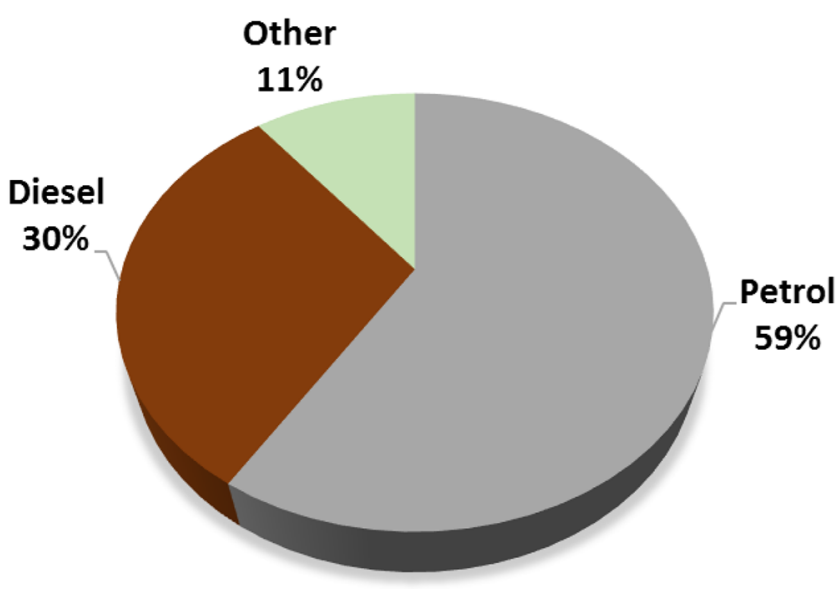

Fig. 4. New cars in the EU by fuel type, 2019 [9].

comprehensive overview of the current situation regarding the use of the three most relevant renewable energy systems in the transport sector, focusing on the EU. The paper contributes to the better understanding of the major impediments and future prospects for the use of renewables in transport.

The main objective of this paper is to document the current state of the three major renewable energy systems in road transport - biofuels, battery electric - and fuel cell vehicles. Based our literature review the major prospects and impediments for the future use of biofuels, renewable electricity and green hydrogen in road transport are discussed considering policies which have been implemented, as well as emission reduction targets set for the future with the special focus on passenger car transport. 
In the next section, the policy framework relevant for the increasing use of renewable energy sources (RES) in the transport sector is documented and discussed with a special focus on passenger car transport. The section about policy framework provides a suitable lead-in to the discussion on biofuels in Section 3, pointing out the most relevant advantages and disadvantages related to biofuel use. In Section 4 we discuss electric vehicles with a special focus on the use of renewable electricity and green hydrogen. Finally, in the last section the major conclusions of this work are provided.

\section{Policy framework}

Over the last years, to cope with the increasing emissions from the transport sector, strong focus has been put on the support of alternative automotive technologies, which have better energy efficiency and better environmental performance, as well as on alternative fuels based on renewable energy sources. About 15 years ago, biofuels were of special interest since they can be blended with conventional fossil fuels and used in ICE vehicles.

Already in 2003, the EU introduced a blending target in the scope of the Biofuels Directive [34]. The first goal was to reach $5.75 \%$ share of biofuels in the transport sector by 2010. In 2009, as part of the European climate and energy package for 2020, the Renewable Energy Directive [35] set the target of $10 \%$ share of renewable energy for 2020 . Moreover, an amendment to the Fuel Quality Directive introduced a mandatory target of a $6 \%$ reduction in GHG intensity of fuels used in the road transport and non-road mobile machinery by 2020 [36].

However, with the increasing use of biofuels also some new challenges and limits have been recognised so that the policy framework has changed over time. In legislation approved by the European Parliament it was decided to cap the amount of crop-based biofuel used in the transport sector at $7 \%$, since crop-based biofuels can have unintended negative impact on environment such as deforestation and food shortages. Moreover, to ensure environmental benefits of biofuels, fuel suppliers are required to report on indirect land use change (ILUC) emissions. In addition, it was decided to stop public support for the crop-based biofuels after 2020.

On 30 November 2016, the European Commission presented a proposal for the promotion of RES, as part of the package 'Clean Energy for all Europeans' [37]. Initially, the main goal was to increase the share of renewable in the European energy mix to at least $27 \%$ by 2030 . In this version of the proposal, a target for RES in the transport sector was excluded. One year later, on 18 December 2017 the Council reached agreement to support the binding target for $27 \%$ of renewables in the energy mix for 2030 . Moreover, a $14 \%$ target for the renewables in the transport sector was proposed. For the first time a target for $3 \%$ share of advanced biofuels was suggested, as well as cap at $7 \%$ share of conventional biofuels [38].

Finally, in Renewable Energy Directive (RED II), the overall EU target for share of RES in energy mix by 2030 has been raised from the originally proposed $27 \%$ to $32 \%$.
Moreover, a sub-target for RES in the transport sector has been included in the final agreement. According to this agreement, EU Member States must have a minimum of $14 \%$ of renewable energy in the energy consumed in the transport by 2030 including a $3.5 \%$ share of advanced biofuels and biogas, and a $7 \%$ cap on the share of first-generation biofuels [38,39].

The revised Renewable Energy Directive (EU) 2018/ 2001, adopted in December 2018 emphasises the sustainability issues related to biofuels production such as indirect land use change (ILUC). Since for the conventional biofuels agricultural products such as corn, wheat, rapeseed, etc., are needed, they are in competition for arable land with food and feed production.

Currently, due to limitations related to the use of biofuels, electrification of mobility gains increasing attention, mostly due to very generous portfolio of monetary and non-monetary supporting measures. Many governments have seen electrification as a good opportunity to reduce local air pollution, as well as global GHG emissions.

Most of the policies implemented on the EU level indirectly support use of electric vehicles. Some of them are the $\mathrm{EU} \mathrm{CO}_{2}$ emission standards for new passenger car [40], the EU climate \& energy packages for 2020 and 2030 [41,42], as well as transport White paper 2011 [43] according to which conventionally-fuelled cars should be removed from cities by 2050 . Ban of conventional vehicles has already started. Already now, many countries have introduced zero-or-low carbon emission zones in city centres. Moreover, some of the countries have announced stop for the registration of new gasoline and diesel vehicles in the coming years. For example, ICE vehicle ban in Norway will start in already 2025, followed by Denmark, Iceland, Ireland, Netherlands and Slovenia in 2030.

Such development is challenging for biofuels. On the one side, this mean that the demand for biofuels will be lower in the passenger car transport, however, on the other side, that demand for so-called zero emission vehicles, such as battery electric vehicles and fuel cell vehicles, will be much higher than today.

Due to the policies implemented the share of renewable energy in the transport sector has been continuously increasing, see Figure 5.

In 2004 share of RES in the transport sector was just $1.4 \%$, and in 2019 more than $8 \%$. Until 2010 , all biofuels were counted as renewable energy sources. However, in 2011 the European Commission set new criteria according to which biofuels could be counted as clean energy, and this change caused a dip in 2011. Although the share of renewable energy is continuously growing this development is still not good enough to stop increase of GHG emission.

\section{Biofuels}

In contrary to fossil fuels, which are the result of a very long process, approximately millions of years, biofuels are made from renewable sources of carbon such as different agricultural products, trees, grasses, etc., which have been harvested recently. Depending on the feedstock used, as well as biofuel production process, biofuels could be divided in different categories, but the major classification is in the 


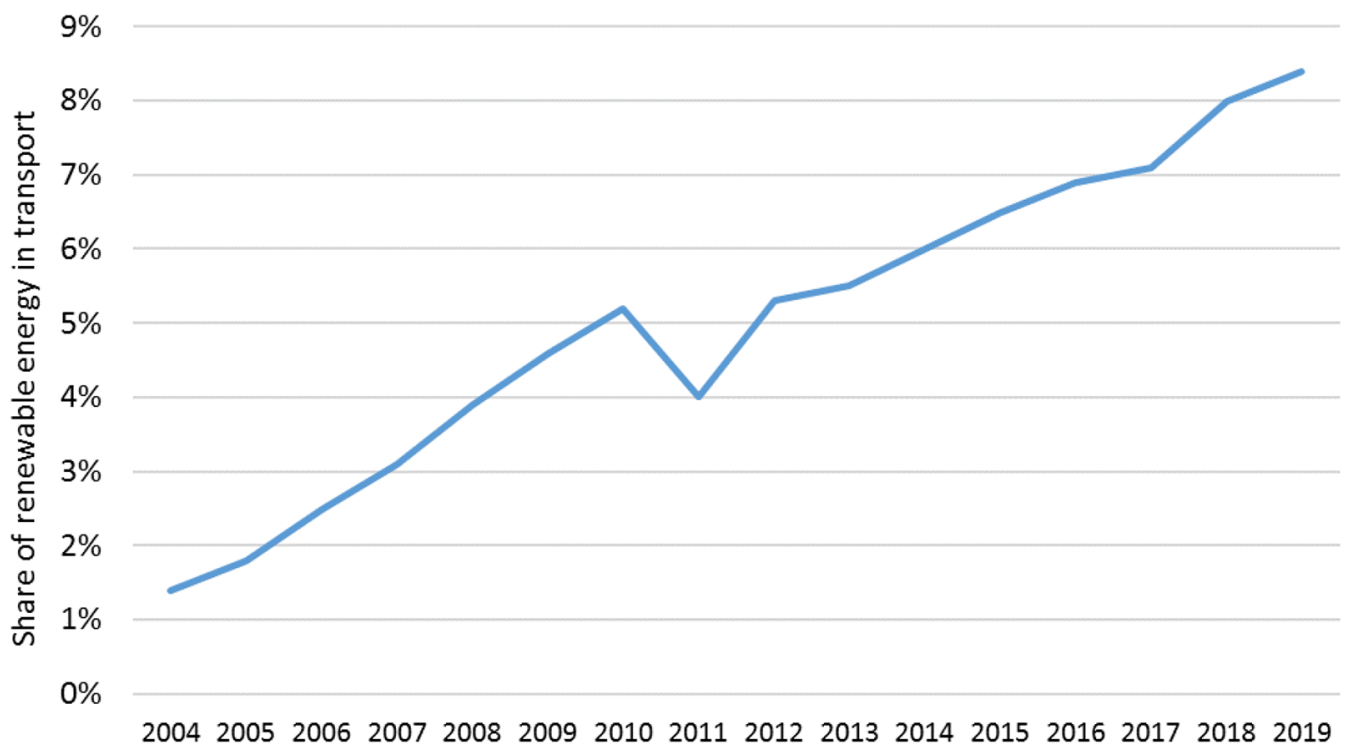

Fig. 5. Share of RES in transport in the EU [44].

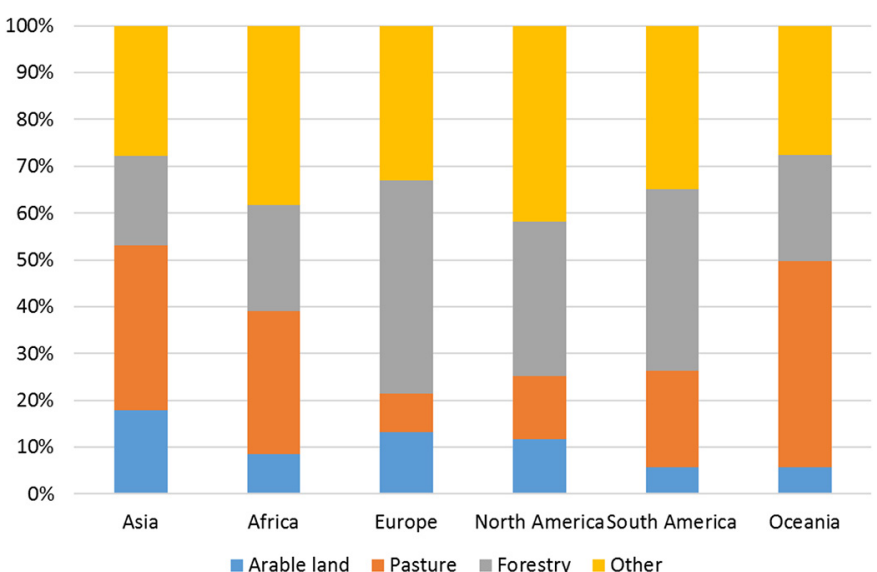

Fig. 6. Share of the global land area [45].

conventional and advanced biofuels. Conventional biofuels are based on agricultural products, which could be also used for food and animal feed. To produce such feedstocks arable land is required, which is very limited all over the world. The total world's land area is roughly 13 Gha, and can be split into four major categories as shown in Figure 6. The share of arable land is very limited in all regions, mostly in the range from about $5 \%$ to $18 \%$ [45]. In Europe it is less than $15 \%$. Globally, there is just about 1.5 Gha of arable land which is to large extend used to grow crops for food and feed.

Increasing biofuel production may lead to the conversion of non-cropland e.g. forests, wetlands and peatlands to agricultural land. A land use change may significantly reduce possible benefits of the GHG savings due to increased biofuels production.

The competition between biofuel and food production could be avoided with advanced biofuels, which could be produced from different lignocellulosic materials such as

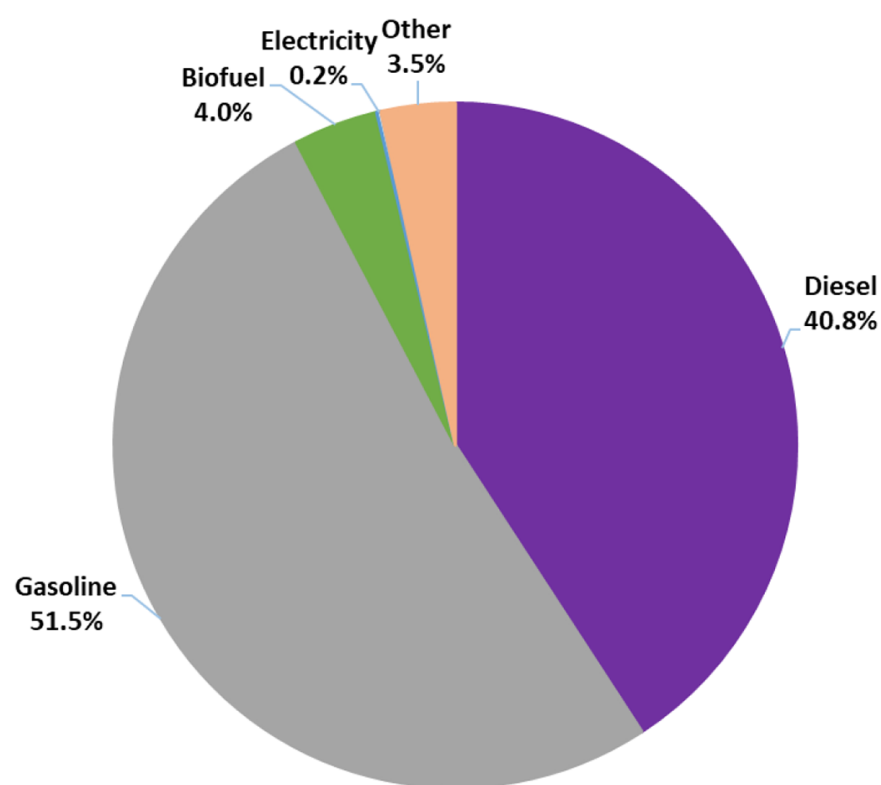

Fig. 7. Global energy consumption in road transport, 2018 [46].

grasses, trees, waste wood from forest industry, etc., so that total potential for biofuel production could be much higher. Such feedstocks are not in competition with food production. Unfortunately, advanced biofuels are still immature. Their production processes have to be improved and production costs reduced. However, already at this stage advanced biofuels have very good environmental performance.

Currently, mostly used are conventional biofuels, bioethanol and biodiesel. The global energy consumption in the road transport is shown in Figure 7 . It can be seen that in 2018, biofuels represented just $4 \%$ of the global energy consumption in the road transport [46]. 


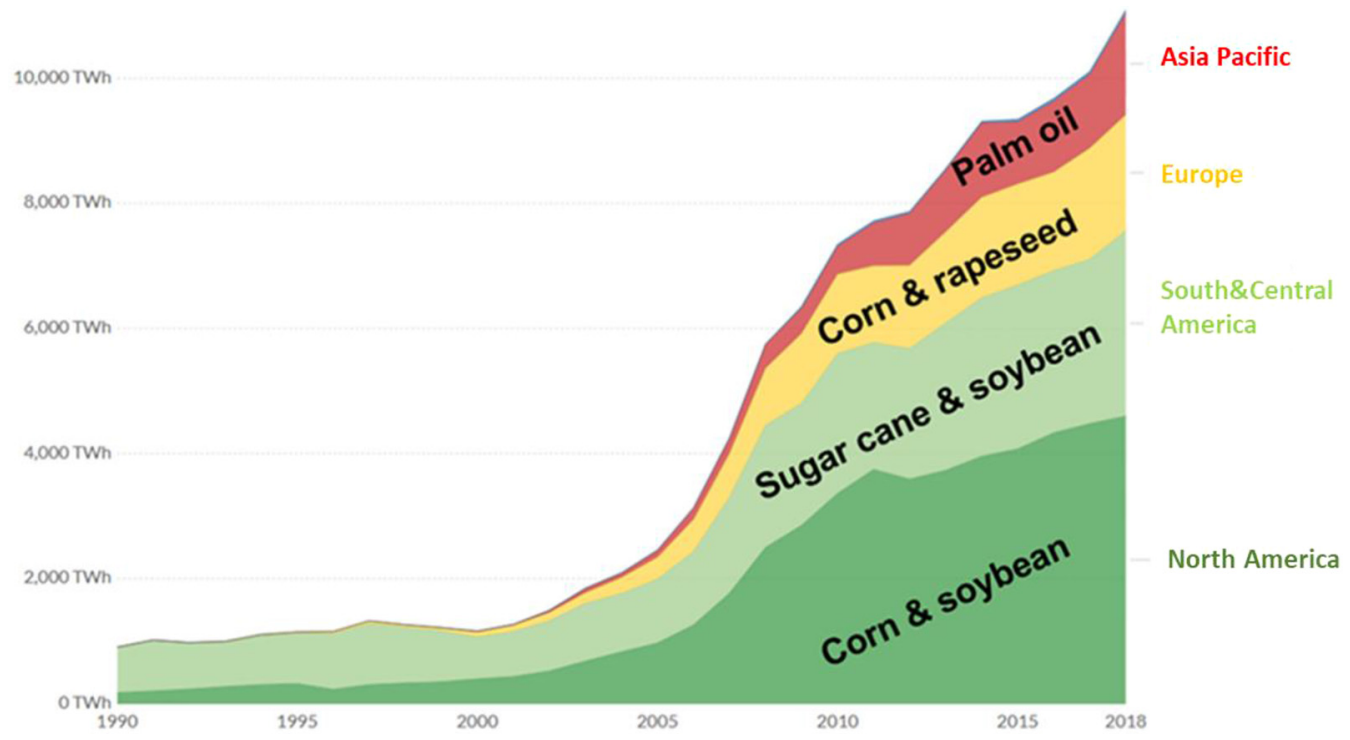

Fig. 8. Biofuels production by region [47].

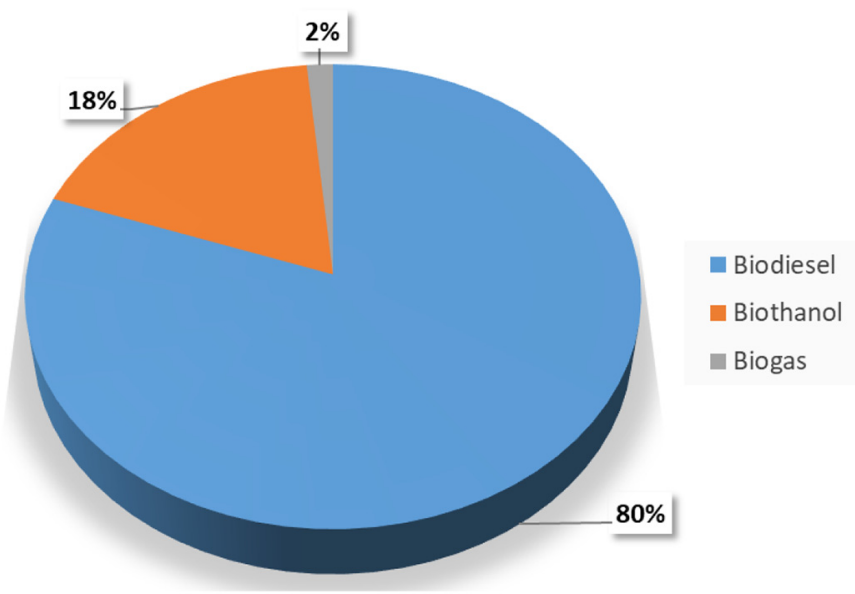

Fig. 9. Biofuels consumption in the EU by fuel type, 2019 [48].

Bioethanol is mostly produced from wheat, corn, sugar beet and sugar cane, and biodiesel from different kinds of vegetable oil (e.g. rape seed, sunflower, and soybean). Which feedstock will be used is very dependent on available land and climate conditions. As it can be seen in Figure 8 biofuel production is increasing all over the world, however, in different regions different feedstocks are used for biofuel production. For example, in North America, predominant feedstocks are corn and soybean, in South- and Central America sugar cane and soybean, and in Europe corn and rapeseeds.

Global bioethanol production is much higher than biodiesel production, but biodiesel is the most important alternative fuel in the EU $[47,48]$. As illustrated in Figure 9, in 2019 biodiesel was the most consumed biofuel type, with the share of more than $80 \%$. In the EU bioethanol accounted for $18 \%$ and biogas for less than $2 \%$ of total biofuel consumption [48].

Regarding the total biofuels production there are significant differences across the EU countries. In 2019, the largest biofuel production was in Germany, about 143 PJ,

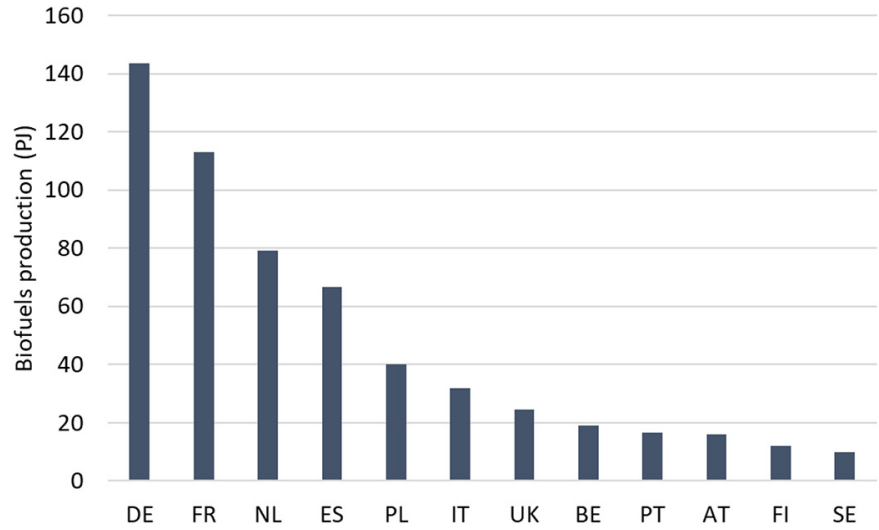

Fig. 10. Biofuels production in the selected EU countries, 2019 [49].

followed by France and the Netherland with 113 PJ and 79.2 PJ respectively [49]. The countries with the highest biofuel production in 2019 are presented in Figure 10.

The demand for biofuels is mostly triggered by supporting policies and ambitious EU targets. However, with the increasing use of biofuels also some challenges and limits have been recognised, as well as the need to switch to the advanced, second-generation biofuels. Yet, to accelerate the use of second-generation biofuels their costs competitiveness with other biofuels and fossil fuels should be significantly improved.

Changeable policy framework, announced ban of ICE vehicles as well as increasing attractiveness of electric vehicles, have affected the investment in biofuel technologies. After the early enthusiasm between 2004 and 2007, global investment in biofuel sector has been on the decreasing trend, see Figure 11. Over the last years investment in biofuels has been marginal in comparison to other renewable energy investments, e.g. wind power and solar photovoltaic $[2,50]$. 


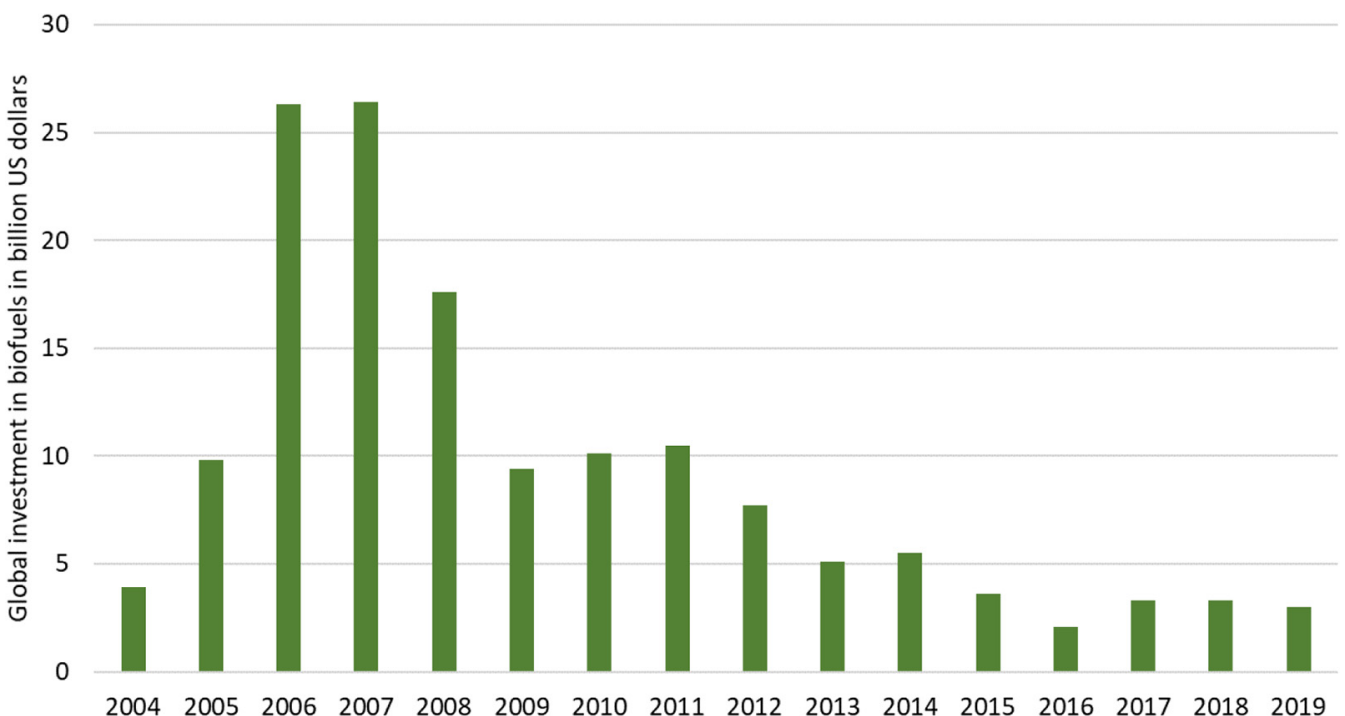

Fig. 11. Global investment in biofuels [50].

Moreover, the COVID crisis has impacted all segments of our life, but especially our mobility [51,52]. Due to the mobility restrictions the demand for oil products and consequently for biofuels was extremally reduced in 2020 . Since bioethanol is mainly used in passenger cars, it was much more affected by this crisis than biodiesel which has a broader use. For example, in Europe, in 2020 demand for bioethanol was reduced by about $13 \%$, and for biodiesel by just about $7 \%[46]$.

There are different scenarios regarding the future development of biofuels. According to some optimistic estimates, biofuel could contribute about one-third of the global fuel supply by 2050 under assumption that 2nd and 3rd generations biofuels are commercially available by 2030 [53]. However, biofuels' future depends on the development of oil prices, investments, and policy preferences. With the ban of ICE passenger cars, biofuels will be more used in other transport modes e.g. in aviation, shipping and heavy goods vehicles. In such transport mode is also competition with electric vehicles very low, at least for now.

\section{Electric vehicles}

Over the last decade electrification of mobility, especially passenger road transport is widely supported and promoted in many countries worldwide [54]. Although electric vehicles are not new technology, through significant improvements of battery performances, electric vehicles have got a new chance recently. In general, electric vehicles have potential to reduce local air pollution and depending on the energy sources used for electricity generation, they can also contribute to the reduction of the global GHG emissions. However, it is important to notice that different types of electric vehicles, such as hybrid electric vehicles (HEV), plug-in hybrid vehicles (PHEV), battery electric vehicle (BEV) and fuel cell electric vehicles (FCEV), have different characteristics and different impact on the environment.
All hybrid vehicles are using, at least to some extent, fossil fuels and they can play important role in the transition towards complete electrification. Due to the announced ban of fossil fuels in transport, in the future it is likely that hybrid vehicles will be increasingly dependent on biofuels. However, since full environmental benefits of electric vehicles could be reached only in combination with renewables, for the future of special interest are so-called zero-emission vehicles, BEV and FCEV.

\subsection{Electricity and battery electric vehicles}

Electricity use in the transport sector has a very long tradition, and different types of electric vehicles, e.g. trams, train, subway, etc., are proven and very successful technologies [55]. However, due to the raising emissions from the road transport, currently special effort is put in the electrification of the passenger cars, as well as urban buses.

Number of battery electric vehicles is increasing all over the world. In 2019, worldwide there were about 4.8 million $\mathrm{BEV}$, most of them in China. However, also in Europe electrification of mobility is progressing, reaching almost one million in 2019 [56], see Figure 12.

Since BEV is still expensive in comparison to conventional cars, in spite of different incentives provided by governments, they are mostly used in the EU countries with the higher GDP per capita. Recently, it can be noticed a continuous shift from direct subsidies to policy approaches that rely more on regulatory and other structural measures, including zero-emission vehicles mandates and fuel economy standards. This should give strong and long-term signal to the auto industry and consumers.

All policies applied have as a final goal to reduce GHG emissions from the transport sector. However, to reach significant emission reduction it is important to increase 
use of zero-emission vehicles (ZEV), but also to increase use of renewable energy sources in electricity generation. Currently, electricity generation mix is very different across the EU, see Figure 13, so that the benefits of electrification are very different. Use of BEV in countries with the high share of fossil energy will contribute just for the improvement of the local air pollution, but not significantly to the reduction of the global GHG emissions [57].

However, one of the priorities of the European policy is to increase the share of RES in electricity mix [41,42], and this will increasingly improve environmental benefits of EV. Yet, it is important to note that currently (except on some single days) in no country excess electricity from RES is available and hence, the by far largest share of electricity used in BEV and for hydrogen production comes from conventional primary energy sources.

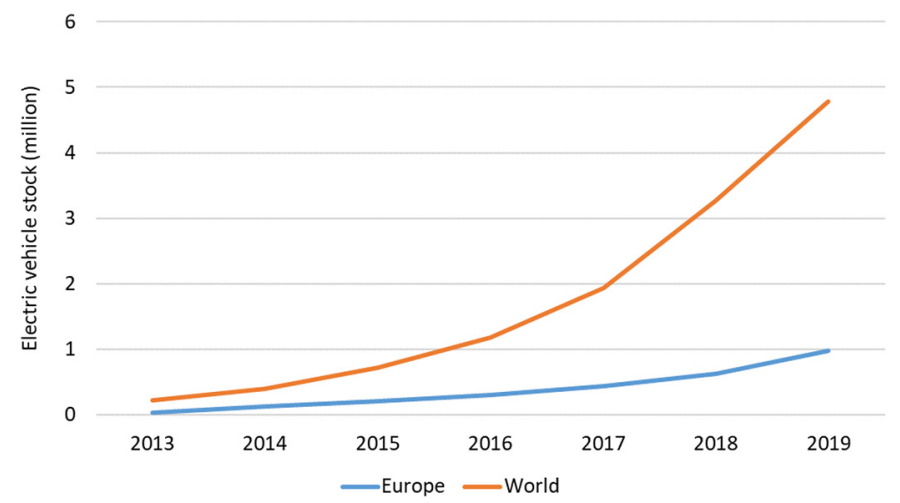

Fig. 12. Battery electric car stock, 2013-2019 [56].

\subsection{Hydrogen and fuel cell vehicles}

A special type of electric vehicles is fuel cell vehicles. In such vehicles, instead to charge battery at the charging stations, hydrogen is refuelled, stored and finally used to produce electricity on board.

Hydrogen is like electricity a secondary energy carrier and can be produced using different primary energy sources including fossil energy and renewable energy. Hydrogen produced from renewable energy sources is usually called green hydrogen.

However, currently the largest amount of hydrogen is produced using fossil energy, especially natural gas. The steam reforming of natural gas is well developed process with relatively low costs. Currently, hydrogen is used in different industries such are refinery, ammonia production, etc. In such cases low cost are priority and not environmental benefits.

Nevertheless, if hydrogen is considered as an energy carrier for the use in the transport sector, good environmental performance is becoming priority.

One of the major obstacles for the larger use of green hydrogen and fuel cell vehicles are high cost. The costs of green hydrogen are more than two time higher in comparison to grey hydrogen produced from fossil fuels. Moreover, FCEV are still very expensive automotive technology, so that the total number of FCV worldwide is increasing but still very low. In 2019 global stock of FCEV was just about 25,000 [59].

However, since hydrogen can be used as a storage for surplice electricity from renewable energy sources, with the increasing use of renewables in electricity generation hydrogen will become important for supply and demand balancing [60,61]. In the long-term green hydrogen can be also used in the transport sector. It is important to recognise that both BEV and FCEV have same advantages

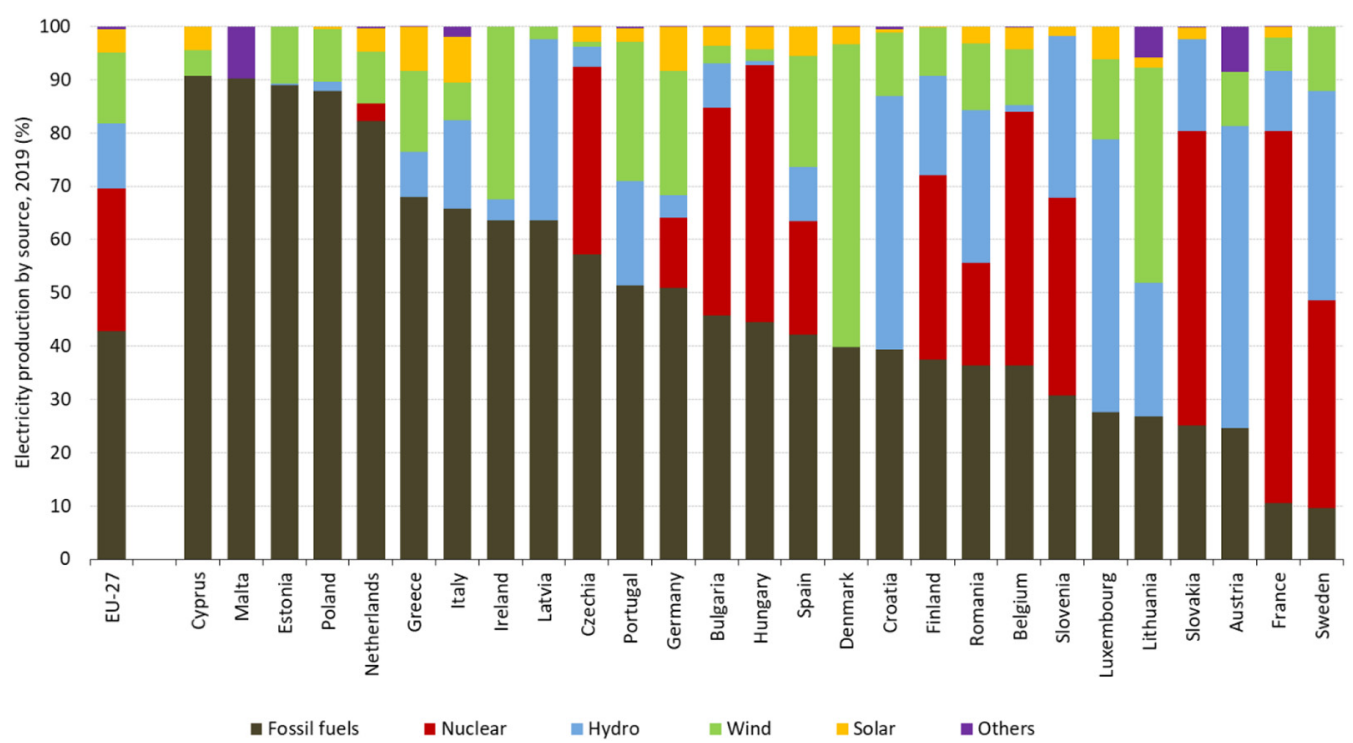

Fig. 13. Electricity production by source, 2019 [58]. 


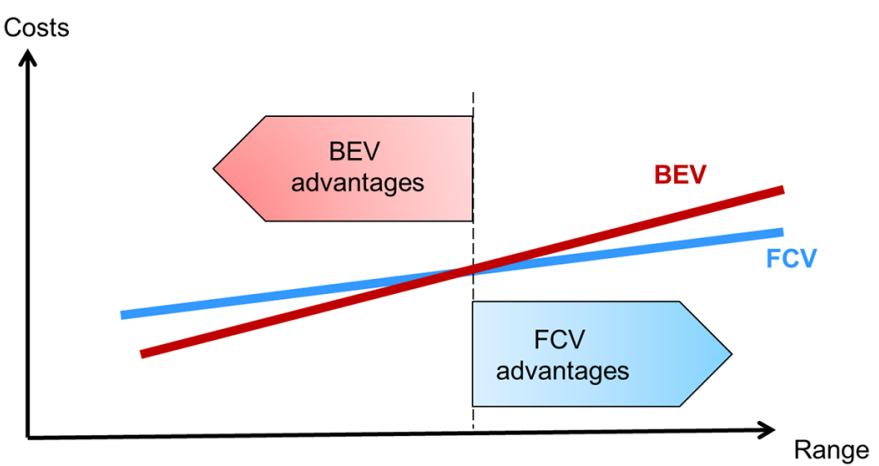

Fig. 14. Costs vs range, BEV and FEV.

and disadvantages, and they are complementary technologies. As illustrated in Figure 14, BEVs have economic advantages in urban areas, where lower driving range is needed and charging infrastructure is sufficiently provided. However, FCEV are more suitable technology for the larger vehicles which can be used over longer distances.

\section{Conclusions}

Renewables in transport have not been a real success story so far. While alternative technologies and energy carriers have been well-known more or less for more than 100 years (e.g. BEV, FCEV or hydrogen), progress over the last decades has been modest [62].

Based on the comprehensive literature review and discussion provided in this paper major conclusions can be derived as follows:

To highlight the most important findings and critical points of this study:

1. Regarding biofuels the major conclusion is that their future use is very dependent on the development of their economic and environmental performance as well as on land availability. The food versus fuel discussion is still on the table and the current $\mathrm{CO}_{2}$ savings are moderate. Moreover, the time of intensive political and financial promotion of biofuels is widely over. Even for advanced $2^{\text {nd }}$ generation biofuels based on lignocellulosic materials there are not many bright prospects on the horizon. Changeable policy framework, including the proposed ban on the sale of new petrol and diesel cars, and unclear long-term visions have a negative impact on the investment in biofuels.

2. With respect to battery electric- and fuel cell vehicles, the major problem for their faster penetration in the market is the high investment costs of vehicles. In the future a significant reduction in these costs can be expected due to technological learning.

However, their contribution to the reduction of the global greenhouse gas emissions is achievable only in combination with the increasing use of renewable energy sources in electricity generation. Moreover, it is important to note that currently, except on some single days, no excess electricity from RES is available. Hence, by far the largest share of electricity used in BEV and for hydrogen production comes from conventional primary energy sources. Another major challenge for the future is to create sustainability standards regarding the mining of materials for battery production, as well as for battery recycling to avoid new environmental problems [63].

The most critical points for the future of renewables in the transport sector are their potential and environmental benefits. A fundamental aspect for biofuels is competition with food and feed production. For the deployment of wind turbines and photovoltaic systems, the major problem is a limited acceptance and availability of suitable locations for their installation.

The most important findings and critical points in this field of study are that there are perspectives for an increased use of RES in the transport sector but we must keep in mind the overall life-cycle balance of all corresponding emissions to avoid the trap of the Green Paradox.

\section{References}

1. IEA, Renewables 2019. Analysis and forecast to 2024 (2019). Available at: https://iea.blob.core.windows.net/assets/ a846e5cf-ca7d-4a1f-a81b-ba1499f2cc07/Renewables_2019. pdf (Accessed: 01 October 2021)

2. REN21, Renewable energy pathways in road transport (2020). Available at: https://www.fiafoundation.org/media/ 791530/renewable-energy-pathways.pdf (Accessed: 01 October 2021)

3. WHO, Air pollution (2021). Available at: https://www.who. int/health-topics/air-pollution\#tab=tab_1 (Accessed: 01 October 2021)

4. REN21, Decarbonising the Transport Sector with Renewables Requires Urgent Action (2020). Available at: https://www.ren21.net/decarbonise-transport-sector-2020/ (Accessed: 01 September 2021)

5. IEA, Energy Efficiency Indicators. Highlights. Statistical Report (2020). Available at: https://webstore.iea.org/down load/direct/4266?fileName=Energy_Efficiency_Indicators Highlights_2020_PDF.pdf (Accessed: 01 September 2021)

6. European Ēnvironmental Agency, Final energy consumption in Europe by mode of transport (2021). Available at: https:// www.eea.europa.eu/data-and-maps/indicators/transport-fi nal-energy-consumption-by-mode/assessment-10 (Accessed: 01 October 2021)

7. European Environmental Agency, Progress of EU transport sector towards its environment and climate objectives (2021). Available at: https://www.eea.europa.eu/publications/prog ress-of-eu-transport-sector-1 (Accessed: 01 September 2021)

8. European Commission, Statistical pocket book 2020 (2020). Available at: https://ec.europa.eu/transport/facts-fund ings/statistics/pocketbook-2020_en (Accessed: 01 September 2021)

9. ACEA, Making the transition to zero-emission mobility. Enabling factors for alternatively-powered cars and vans in the European Union (2020). Available at: https: / www.acea. be/uploads/publications/ACEA_progress_report_2020.pdf\# page $=6$ (Accessed: 01 October $\overline{2021}$ )

10. A. Ajanovic, R. Haas, On the future prospects and limits of biofuels in Brazil, the US and EU. Appl. Energy 135, 730-737 (2014) 
11. K.S. Hoekman, Biofuels in the U.S. - challenges and opportunities, Renew. Energy 34, 14-22 (2009)

12. D. Chakraborty, J.H. Efthi, M. Khanom, I.M. Mahbubul, Prospective and challenging issues of biofuels, EDU J. Comput. Electr. Eng. 1, 4-10 (2020)

13. A.S. Nugroho, C. Thorns, I. Sankoff, S.H. Chew, S. Bista, Transitioning to sustainable use of biofuel in Australia, Renew. Energy Environ. Sustain. 2, 25 (2017)

14. A. Demirbas, Political, economic and environmental impacts of biofuels: a review. Appl. Energy 86, S108-S117 (2009)

15. A. Ajanovic, Renewable fuels - a comparative assessment from economic, energetic and ecological point-of-view up to 2050 in EU-countries, Renew. Energy 60, 733-738 (2013)

16. A. Ajanovic, R. Haas, $\mathrm{CO}_{2}$-reduction potentials and costs of biomass-based alternative energy carriers in Austria, Energy 69, 120-131 (2014)

17. G.P. Hammond, S.M. Seth, Carbon and environmental footprinting of global biofuel production. Appl Energy 112, 547-559 (2013)

18. A. Ayres, Germany's water footprint of transport fuels. Appl. Energy 113, 1746-1751 (2014)

19. M. Wise, J. Dooley, P. Luckow, K. Calvin, P. Kyle, Agriculture, land use, energy and carbon emission impacts of global biofuel mandates to mid-century, Appl. Energy 114, 763-773 (2014)

20. S. Srinivasan, The food vs. fuel debate: a nuanced view of incentive structures, Renew. Energy 34, 950-954 (2009)

21. J.O. Ahmed, The effect of biofuel crops cultivation on food prices stability and food security - a review, EurAsian J. BioSci. 14, 613-621 (2020)

22. A. Ajanovic, Biofuels versus food production: does biofuels production increase food prices? Energy 36, 2070-2076 (2011)

23. Y. Ono, T. Haneda, T. Ikegami, A. Akisawa, Possibility of hydrogen supply by shared residential fuel cell systems for fuel cell vehicles, Renew. Energy Environ. Sustain. 2, 11 (2017)

24. R.H. Bezdek, The hydrogen economy and jobs of the future, Renew. Energy Environ. Sustain. 4, 1 (2019)

25. A. Ajanovic, A. Glatt, R. Haas, Prospects and impediments for hydrogen fuel cell buses, Energy 235, 121340 (2021)

26. H. Zhanga, C.J.R. Sheppard, T.E. Lipman, T. Zeng, S.J. Moura, Charging infrastructure demands of shared-use autonomous electric vehicles in urban areas, Transportation Res. D 78, 102210 (2020)

27. A. Ajanovic, R. Haas, Dissemination of electric vehicles in urban areas: major factors for success, Energy 115, 14511458 (2016)

28. A. Ajanovic, M. Siebenhofer, R. Haas, Electric mobility in cities: the case of Vienna, Energies 14, 217 (2021)

29. S. Xiong, J. Ji, X. Ma, Environmental and economic evaluation of remanufacturing lithium-ion batteries from electric vehicles, Waste Manag. 102, 579-586 (2020)

30. A. Ajanovic, R. Haas, Economic and environmental prospects for battery electric- and fuel cell vehicles: a review, Fuel Cells 19, 515-529 (2019)

31. A. Ajanovic, R. Haas, On the economics and the future prospects of battery electric vehicles, Greenhouse Gas Sci. Technol. 10, 1151-1164 (2020)

32. T. Steenberghen, E. Lopez, Overcoming barriers to the implementation of alternative fuels for road transport in Europe, J. Clean. Prod. 16, 577-590 (2008)
33. D.F. Dominković, I. Bačeković, A.S. Pedersen, G. Krajačić, The future of transportation in sustainable energy systems: Opportunities and barriers in a clean energy transition, Renew. Sustain. Energy Rev. 82, 1823-1838 (2018)

34. DIRECTIVE 2003/30/EC OF THE EUROPEAN PARLIAMENT AND OF THE COUNCIL of 8 May 2003 on the promotion of the use of biofuels or other renewable fuels for transport, https://eur-lex.europa.eu/legal-content/EN/ TXT/PDF/?uri=CELEX:32003L0030\&from=en (Accessed: 01 September 2021)

35. DIRECTIVE 2009/28/EC OF THE EUROPEAN PARLIAMENT AND OF THE COUNCIL of 23 April 2009 on the promotion of the use of energy from renewable sources and amending and subsequently repealing Directives 2001/77/ EC and 2003/30/EC, https://eur-lex.europa.eu/legal-con tent $/ \mathrm{EN} / \mathrm{TXT} / \mathrm{PDF} /$ ?uri=CELEX:32009L0028\&from $=\mathrm{EN}$ (Accessed: 01 September 2021)

36. European Parliament, EU biofuels policy, Briefing, January 2015, https://www.europarl.europa.eu/RegData/etudes/ BRIE/2015/545726/EPRS_BRI(2015)545726_REV1_EN. pdf (Accessed: 01 September 2021)

37. European Commission, Clean energy for all Europeans package, https://ec.europa.eu/energy/topics/energy-strategy/clean-en ergy-all-europeans_en (Accessed: 01 September 2021)

38. European Parliament, Legislative Train. REVIEW OF THE RENEWABLE ENERGY DIRECTIVE 2009/28/EC TO ADAPT IT TO THE EU 2030 CLIMATE AND ENERGY TARGETS, https://www.europarl.europa.eu/legislativetrain/theme-resilient-energy-union-with-a-climate-changepolicy/file-jd-renewable-energy-directive-for-2030-with-sus tainable-biomass-and-biofuels (Accessed: 01 September 2021)

39. ICCT, Final recast renewable energy directive for 2021-2030 in the European Union (2018). Available at: https://theicct. org/sites/default/files/publications/EU_Fuels_Policy_Up date_20180719.pdf (Accessed: 01 September 20̄21)

40. European Commission, Reducing $\mathrm{CO}_{2}$ emissions from passenger cars - before 2020, https://ec.europa.eu/clima/ policies/transport/vehicles/cars_en (Accessed: 01 September 2021)

41. European Commission, 2020 climate \& energy package, https://ec.europa.eu/clima/policies/strategies/2020_en (Accessed: 01 September 2021)

42. European Commission, 2030 climate \& energy framework, https://ec.europa.eu/clima/policies/strategies/2030_en (Accessed: 01 September 2021)

43. European Commission, White paper 2011, https://ec. europa.eu/transport/themes/european-strategies/white-pa per-2011_en (Accessed: 01 September 2021)

44. Statista, Share of energy from renewable sources used in transport in the European Union (EU-28) from 2004 to 2019 (2021), https://www.statista.com/statistics/1193061/renew able-energy-use-for-transport-in-europe/ (Accessed: 01 September 2021)

45. FAO, Global forest resources assessment 2010. FAO Forestry Paper 163. Food and Agricultural Organization of the Unit ed Nations, Rome, Italy, 2010, 378pp

46. IFP, Biofuels Dashboard 2020 (2020). Available at: https:// www.ifpenergiesnouvelles.com/article/biofuels-dashboard2020 (Accessed: 01 September 2021) 
47. BP, Statistical Review of World Energy2020 | 69th edition (2020). Available at: https://www.bp.com/content/dam/ bp/business-sites/en/global/corporate/pdfs/energy-econom ics/statistical-review/bp-stats-review-2020-full-report.pdf (Accessed: 03 October 2021)

48. Statista, Distribution of biofuel consumption in energetic content for transport in the European Union (EU-28) in 2019, by fuel type (2021). Available at: https://www.statista.com/ statistics/275573/eu-distribution-of-biofuel-consumption/ (Accessed: 03 October 2021)

49. Statista, Biofuels production in selected countries in Europe in 2019 (2021). Available at: https://www.statista.com/ statistics/332510/biofuels-production-in-selected-countriesin-europe/ (Accessed: 03 October 2021)

50. Frankfurt School-UNEP Collaborating Centre for Climate \& Sustainable Energy Finance (FS-UNEP) and BloombergNEF. (2019). Global Trends in Renewable Energy Investment. Available at: https://www.unenvironment.org/ resources/report/global-trends-renewable-energy-investment2019 (Accessed: 03 September 2021)

51. IEA, Global Energy Review 2020 (2020). Available at: https://webstore.iea.org/download/direct/2995 (Accessed: 03 September 2021)

52. S. Nizetic, Impact of coronavirus (COVID-19) pandemic on air transport mobility, energy, and environment: a case study, Int. J. Energy Res. 44, 10953-10961 (2020)

53. IEA, Technology Roadmap. Biofuels for Transport (2011). Available at: https://www.ieabioenergy.com/wp-content/ uploads/2013/10/IEA-Biofuel-Roadmap.pdf (Accessed: 03 September 2021)
54. M. Siebenhofer, A. Ajanovic, R. Haas, How policies affect the dissemination of electric passenger cars worldwide, Energies 14, 2093 (2021)

55. A. Ajanovic, R. Haas, M. Schrödl, On the historical development and future prospects of various types of electric mobility, Energies 14, 1070 (2021)

56. IEA, Global EV Outlook 2020 (2020). Available at: https:// webstore.iea.org/download/direct/3007 (Accessed: 03 September 2021)

57. A. Ajanovic, R. Haas, Electric vehicles: solution or new problem? Environ. Dev. Sustain. 20, 7-22 (2018)

58. Eurostat, Electricity generation statistics (2021). Available at: https://ec.europa.eu/eurostat/statistics-explained/in dex.php/Electricity_generation_statistics_\%E2\%80\%93_ first_results \#Production_of_electricity ${ }^{-}$(Accessed: $\overline{03}$ September 2021)

59. G. Gardiner, The markets: Fuel cells and batteries (2020). Available at: https://www.compositesworld.com/articles/ the-markets-fuels-cells-and-batteries (Accessed: 01 Octobre 2021)

60. J. Ramsebner, R. Haas, A. Ajanovic, M. Wietschel, The sector coupling concept: a critical review, WIREs Energy Environ. 396 (2021)

61. A. Hiesl, A. Ajanovic, R. Haas, On current and future economics of electricity storage, Greenhouse Gas Sci. Technol. 10, 1176-1192 (2020)

62. A. Ajanovic, The future of electric vehicles: prospects and impediments, WIREs Energy Environ. 4, 521-536 (2015)

63. A. Ajanovic, R. Haas, On the environmental benignity of electric vehicles, J. Sustain. Dev. Energy Water Environ. Syst. 7, 416-431 (2019)

Cite this article as: Amela Ajanovic, Reinhard Haas, Renewable energy systems implementation in road transport: prospects and impediments, Renew. Energy Environ. Sustain. 6, 39 (2021) 